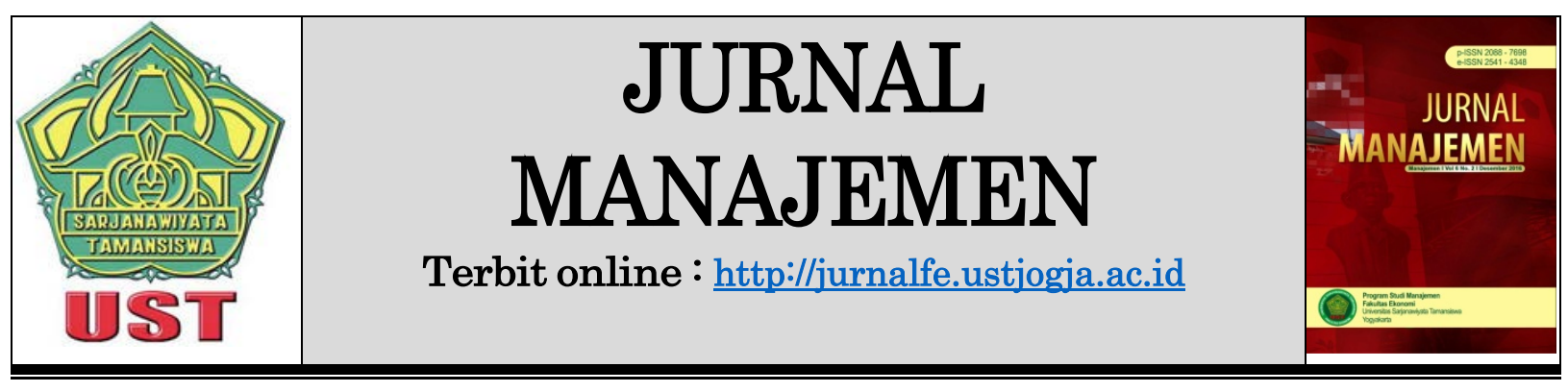

\title{
PENERAPAN BUDAYA ORGANISASIONAL YANG BERETIKA BISNIS PADA PERUSAHAAN DI INDUSTRI PENERBANGAN INDONESIA
}

\author{
Dhiani Dyahjatmayanti ${ }^{1}$ \\ You She Melly Anne Dharasta ${ }^{2}$
}

${ }^{1,2}$ Dosen Sekolah Tinggi Teknologi Kedirgantaraan, Yogyakarta

Korespondensi:1dhiani.dyahjatmayanti@sttkd.ac.id,2you.she.m.a.d@sttkd.ac.id

\begin{tabular}{lc}
\hline Informasi Naskah & Abstrak \\
\hline Diterima: & Ethic holds an important role in business organization. \\
09 Oktober & This means that anyone conducting in aviation industry \\
Revisi: & needs to imbue themselves with noble ethic and also moral \\
11 Oktober & responsibilities. Concerning to the importance of ethic in \\
Terbit: & business, the researchers believe that it is important to know \\
16 Desember & how airline companies face the crucial problems in their \\
\hline Kata Kunci: & practice. This study aims at analyzing the influence of \\
Organizational & organizational culture on the implementation of the business \\
Culture, Business & ethics of the Indonesian aviation industry. \\
Ethics, Aviation & This is a descriptive quantitative study. The primary \\
Industry & data were collected through questionnaires and interview to \\
& the employees in aviation company in Indonesia. The \\
& primary data from the questionnaires were analyzed using \\
& simple regression and coefficient. The data from the \\
& interview were analyzed using content analysis. \\
& The result showed that the companies already have the \\
& code of conduct for the employees and stakeholders. The $F-$ \\
& test revealed that the company culture influence the \\
implementation of the business ethics of the Indonesian \\
aviation industry. The simple linear regression showed the \\
positive relationship between the organization culture and \\
the Business ethic. The coefficient determination revealed \\
that organization culture contribute to the 18,92\% on the \\
implementation of the business ethics, while the 81,08\% is \\
caused by other variables.
\end{tabular}

\section{PENDAHULUAN}

Pada masa moderen seperti saat ini, perusahaan dalam suatu industri berusaha untuk mendapatkan tingkat keuntungan yang tinggi. Persaingan global dan ketat, ledakan teknologi informasi, dan munculnya ekonomi berbasis pengetahuan secara terus-menerus membentuk kembali lingkungan bisnis dunia 
(Thompson, 1995). Adanya perkembangan teknologi informasi yang sangat pesat memudahkan pelaku bisnis sekaligus membuat bisnis menjadi transparan. Dalam dunia bisnis, etika memiliki peran penting bagi organisasi bisnis. Bisnis merupakan aktivitas yang memerlukan tanggung jawab moral dalam pelaksanaannya, sehingga etika dalam praktik bisnis memiliki hubungan yang erat. Bisnis tanpa etika akan membuat praktik bisnis menjadi tidak terkendali dan justru merugikan tujuan utama dari bisnis itu sendiri. Etika dilaksanakan sesuai dengan tuntutan kebutuhan dunia bisnis. Etika menuntut agar seseorang melakukan ajaran moral tertentu karena ia sadar bahwa hal itu memang bermanfaat dan baik bagi dirinya dan orang lain (Keraf,1998).

Perusahaan yang unggul sebaiknya tidak hanya tergantung pada kinerja yang baik, pengaturan manajerial dan finansial yang baik, keunggulan teknologi yang dimiliki, sarana dan prasarana yang dimiliki melainkan juga harus didasari dengan etika bisnis yang baik. Dengan memperhatikan etika bisnis yang baik maka kepercayaan seluruh stakeholder terhadap perusahaan tetap terjaga. Hal ini tentunya membantu perusahaan dalam menciptakan citra bisnis yang baik dan etis. Namun, para ahli bisnis sering mengatakan bahwa etika bisnis adalah sebuah kontradiksi istilah karena terjadi pertentangan inheren antara etika dan dan orientasi kepentingan pribadi dalam bisnis yaitu berupa profit (Velasquez, 2006). Sementara, dengan menerapkan tanggung jawab sosial dan perilaku etis dalam bisnis dapat menjadi keunggulan kompetitif jangka panjang bagi perusahaan (Militaru \& Zanfir, 2012).

Pada era moderen saat ini, isu mengenai etika dan perilaku etis mendapatkan perhatian yang lebih besar. Minat tersebut sebagian disebabkan karena kasus-kasus yang bersifat meragukan atau perilaku tidak etis yang potensial dan berhubungan dengan biaya (Kreitner dan Kinicki, 2010). Sebagai contoh, industri-industri di Amerika Serikat merugi sekitar 400 miliar dolar AS dalam satu tahun karena perilaku kriminal dan tidak etis. Survei lainnya menunjukkan bahwa $20 \%$ dari responden yang diminta melakukan sesuatu yang bertentangan dengan standar etis mereka, 41\% menurutinya (Wah, 1999). Perilaku yang tidak etis merupakan permasalahan yang relevan bagi semua karyawan. Hal ini muncul dari tingkat dasar sampai puncak organisasi (Kreitner dan Kinicki, 2010). Survei lainnya yang dilakukan terhadap 1000 eksekutif senior menunjukkan bahwa sebanyak sepertiga dari mereka berbohong pada kesimpulan. Hal ini mungkin tidak mengejutkan karena dengan berbohong banyak keuntungan yang didapat seperti gaji yang lebih tinggi dan saham, dan persaingan untuk menduduki posisi manajemen senior (Wah, 1999). Berdasarkan hasil survei-survei tersebut, terdapat beragam karakteristik individu dan organisasi yang memiliki kontribusi terhadap perilaku yang tidak etis.

Saat ini, manusia dihadapkan pada aktivitas yang padat dengan mobilitas yang tinggi, sehingga membutuhkan sarana transportasi yang cepat. Oleh karena itu, industri penerbangan terus berkembang dan menimbulkan tingkat persaingan yang tinggi. Dinamika yang ditandai dengan pertumbuhan perusahaan dan penumpang ini tidak bisa dihindari terjadi permasalahan-permasalahan dalam bisnis penerbangan. Para pelaku bisnis dalam mencapai target-targetnya mengerahkan strategi masing-masing yang dalam kenyataannya sering terjadi benturan kepentingan. Disinilah etika bisnis jasa penerbangan menjadi salah satu instrumen dalam menjaga kelangsungan jasa penerbangan.

Memetik dari pentingnya sikap etik dalam kehidupan bisnis maka dianggap penting untuk mengetahui bagaimana perusahaan menghadapi masalah-masalah yang krusial dalam menjalankan praktik etika bisnis. Budaya organisasi memiliki peranan penting dalam penerapan etika bisnis perusahaan. Oleh karena itu, pada penelitian ini mengkaji pengaruh budaya organisasional terhadap penerapan etika 
bisnis pada perusahaan di industri penerbangan.

Tujuan dari penelitian ini adalah menganalisis pengaruh budaya organisasional terhadap penerapan etika bisnis dan menganalisis penerapan standar etika di perusahaan pada industri penerbangan Indonesia. Hasil penelitian ini diharapkan dapat memberikan gambaran dan masukan bagi perusahaan di industri penerbangan mengenai seberapa besar pengaruh budaya organisasional mendorong perilaku yang etis dan mendukung penerapan etika bisnis di perusahaan, sehingga perusahaan dapat meningkatkan kinerja bisnisnya dan meningkatkan kepercayaan para stakeholder. Selain itu, penelitian ini berkontribusi terhadap pengetahuan atau teori yang diwujudkan dalam bentuk review dan penambahan wawasan keilmuan mengenai penerapan etika bisnis di perusahaan atau industri penerbangan.

\section{KAJIAN PUSTAKA DAN HIPOTESIS Hakikat dan Pengertian Etika Bisnis}

Kata etis - dalam pemahaman penulis merujuk pada pemahaman buku-berarti sesuatu hal yang terpikir, terasakan, dan dipercaya bahwa hal itu adalah benar serta sesuai dengan pemahaman religius dalam memberikan dominasi peraturan dalam kehidupan secara pribadi maupun social. Sementara etika menurut gramatikal kamus adalah prinsip tingkah laku yang mengatur individu ataupun kelompok yang berupa "kajian moralitas". Secara singkat dapat kita perjelas bahawa etika adalah penelaahan terhadap subyek moralitas (Velasquez, 2006). Pengertian ini selaras dengan yang diungkapkan oleh Griffin dan Ebert (2010), etika merupakan keyakinan mengenai tindakan yang benar dan yang salah, atau tindakan yang baik dan yang buruk yang mempengaruhi hal lainnya. Perilaku etis merupakan perilaku yang mencerminkan keyakinan perseorangan dan norma-norma sosial yang diterima secara umum sehubungan dengan tindakan-tindakan yang benar dan baik. Perilaku tidak etis adalah perilaku yang menurut keyakinan perseorangan dan norma-norma sosial dianggap salah atau buruk.

Perilaku etis berhubungan dengan moralitas. Secara definisi singkat dapat dijelaskan bahwa moralitas adalah suatu pedoman yang mengatur tentang apa yang benar dan apa yang salah, apa yang baik dan apa yang buruk. Tentunya untuk meuniversal-kan suatu pedoman dalam memberikan nilai moralitas yang benar, maka harus ditentukan standart-standart tertentu dalam perkembangannya. Standart tersebut dapat kita sebut sebagai "Standar Moral". Standar moral memiliki nilai esensial tersendiri dalam menjalankan fungsinya sebagai pedoman moralitas yaitu berupa sebuah standart moral berkaitan dengan hal yang mempunyai konsekuensi yang serius, melampaui kepentingan pribadi ,didasarkan pada penalaran yang baik bukan otoritas, didasarkan pada pertimbangan yang tidak memihak dan pelanggarannya di asosiakan dengan perasaan bersalah,malu atau dengan kosa kata moral tertentu (Velasquez, 2006). Dengan adanya standar moral tersebut dapat ditentukan apakah suatu tindakan tersebut bermoral atau tidak, sehingga dalam range tertentu dapat dipelajari kajian-kajian etika dalam bidang tertentu, seperti dalam bidang bisnis yang dikaji melalui genre Studi Etika Bisnis.

Etika bisnis adalah suatu studi yang berkonsentrasi pada nilai moral dan penerapan standar moral dalam kebijakan institusi dan perilaku bisnis. Tentunya dalam penerapan nilai moral dan standart moral ini akan mengatur bagaimana sebuah perusahaan dalam bersikap menjalankan bisnisnya (Velasquez, 2006). Menurut Etika bisnis adalah istilah yang biasanya berkaitan dengan perilaku etis atau tidak etis yang dilakukan oleh manajer atau pemilik suatu organisasi Griffin dan Ebert (2010). 


\section{Pembentukan Budaya Organisasional}

Menurut Kreitner dan Kinicki (2010), budaya organisasional merupakan nilai dan keyakinan bersama yang mendasari identitas perusahaan. Budaya organisasional adalah satu wujud anggapan yang dimiliki, diterima secara implisit oleh kelompok dan menentukan bagaimana kelompok tersebut rasakan, pikirkan, dan bereaksi terhadap lingkungannya yang beraneka ragam (Schein, 1996). Definisi ini menyoroti tiga karakteristik budaya organisasional yang penting. Pertama, budaya organisasi diberikan kepada karyawan baru melalui proses sosialisasi. Kedua, budaya organisasional mempengaruhi perilaku karyawan di tempat kerja. Akhirnya, budaya organisasional berlaku pada dua tingkat yang berbeda. Masingmasing tingkat bervariasi dalam kaitannya dengan pandangan ke luar dan kemampuan bertahan terhadap perubahan (Schein, 1992).

\section{Nilai-nilai Organisasi: Dasar Budaya Organisasional}

Nilai-nilai dan keyakinan organisasi merupakan dasar budaya organisasional. Keduanya juga memainkan peranan penting dalam mempengaruhi etika berperilaku (Kreitner dan Kinicki, 2010). Ada dua nilai organisasi, yaitu nilai pendukung (espaused values) dan nilai yang diperankan (enacted values). Nilai pendukung (espaused values) menunjukkan nilai-nilai yang dinyatakan secara eksplisit yang dipilih oleh organisasi. Umumnya, nilai pendukung dibentuk oleh pendiri perusahaan atau tim top management. Nilai yang diperankan (enacted values) merupakan nilai dan norma yang sebenarnya ditunjukkan atau dimasukkan ke dalam perilaku karyawan.

\section{Model Perilaku Etis}

Tingkah laku dan tindakan etis merupakan produk dari kombinasi pengaruh yang kompleks. Pada bagian tengah model Gambar 1 adalah pembuat keputusan individu. Individu memiliki kombinasi karakteristik kepribadian, nilai, dan prinsip moral yang unik, yang berlandaskan pada perilaku etis maupun tidak etis. Selanjutnya, Gambar 1 menggambarkan tiga sumber pengaruh utama terhadap peran yang diharapkan pada seseorang. Orang-orang memainkan banyak peran dalam kehidupan termasuk karyawan atau manajer. Harapan seseorang mengenai bagaimana peran tersebut harus dimainkan dibentuk oleh faktor budaya, organisasi, dan lingkungan umum. Terdapat pula pengaruh-pengaruh yang mengganggu organisasi. Banyak penelitian telah menemukan kecenderungan pada manajer tingkat menengah dan yang lebih rendah untuk bertindak tidak etis dalam menghadapi tekanan. 


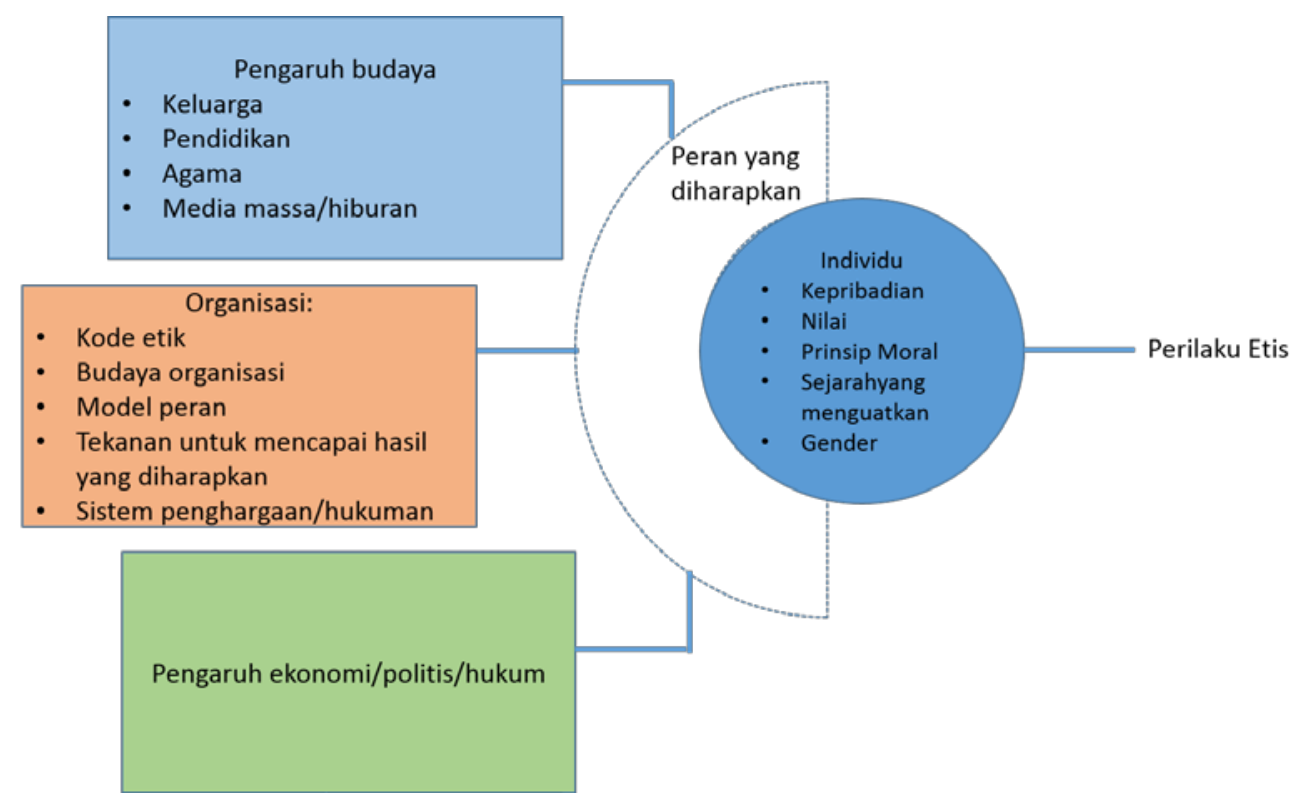

Gambar 1 Model Etika Berperilaku di Tempat Kerja (Kreitner dan Kinicki, 2010)

\section{Mengembangkan Iklim Etika Bisnis dalam Organisasi}

Organisasi berusaha mendorong perilaku etis dan melarang perilaku tidak etis dengan berbagai cara, misalnya menetapkan aturan main dalam menjalankan dan mengembangkan posisi etis yang jelas mengenai cara perusahaan dan karyawan menjalankan bisnisnya (Griffin \& Ebert, 2010). Umumnya langkah tunggal paling efektif yang dapat diambil perusahaan adalah memperlihatkan dukungan manajemen puncak terhadap tindakan yang etis. Dua pendekatan paling umum untuk membentuk komitmen manajemen puncak terhadap praktek bisnis yang etis adalah membuat peraturan tertulis atau disebut dengan kode etik dan memberlakukan program etika. (Griffin \& Ebert, 2010).

Kode etik adalah dokumen tertulis berupa prinsip filosofis dan mengartikulasikan nilai-nilai yang dipeluk oleh organisasi (Stevens, 1996). Kode mengartikulasikan parameter etika organisasi yaitu apa yang bisa diterima dan apa yang tidak (Stevens, 2008). Gambar 2 mengilustrasikan peranan penting etika dan nilai yang harus digunakan dalam kebijakan korporasi. Pada dasarnya, gambar tersebut menyarankan bahwa walaupun strategi dan praktik bisnis bisa sering berubah, bahkan tujuan bisnis kadang-kadang berubah, prinsip inti dan nilai organisasi harus tetap bertahan yang tertuang dalam kode etik perusahaan (Griffin \& Ebert, 2010). Budaya bisnis merupakan elemen yang kompleks yang merefleksikan budaya organisasional dan komponen-komponennya seperti pendekatan etika dalam bisnis, penerapan tanggung jawab sosial, dan menjaga etiket dalam setiap perilaku bisnis (Militaru \& Zanfir, 2012). 


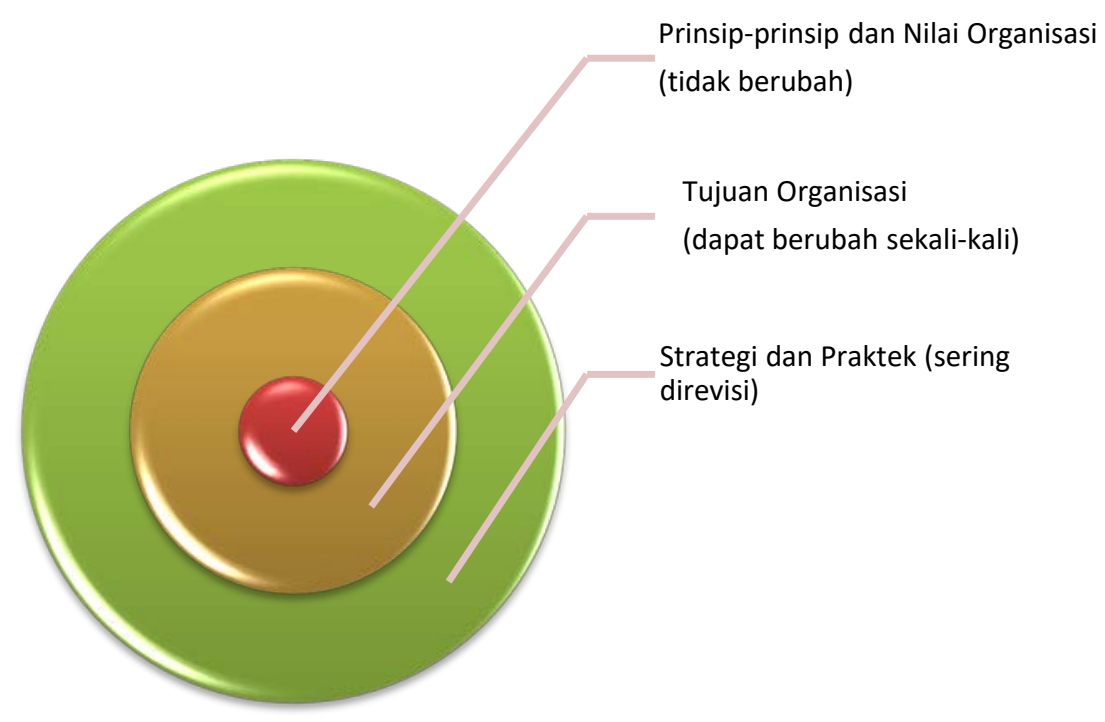

Gambar 2. Prinsip-prinsip inti dan nilai-nilai organisasi

\section{Pengembangan Hipotesis}

Hipotesis dalam penelitian ini adalah sebagai berikut:

$H_{0}$ : Tidak ada pengaruh budaya organisasional terhadap penerapan etika bisnis di perusahaan industri penerbangan.

$H_{1}$ : Ada pengaruh budaya organisasional terhadap penerapan etika bisnis di perusahaan industri penerbangan.

\section{METODE PENELITIAN}

Penelitian ini menggunakan pendekatan kuantitatif. Penelitian dilakukan di Indonesia dengan objek penelitian adalah 4 (empat) perusahaan pada industri penerbangan di Indonesia. Pendekatan kuantitatif dilakukan untuk menghasilkan fakta spesifik yang dapat digunakan untuk membuat prediksi akurat mengenai hubungan antara budaya organisasional dengan penerapan etika bisnis, memperoleh informasi tentang suatu hubungan, memastikan hubungan yang sudah ada, dan menguji hipotesis. Gambar 3 menunjukkan model penelitian yang digunakan. Pada penelitian ini melihat hubungan antara budaya organisasi dengan penerapan etika bisnis.

$(\mathrm{x})$

Independent Variable (y)

Dependent Variable

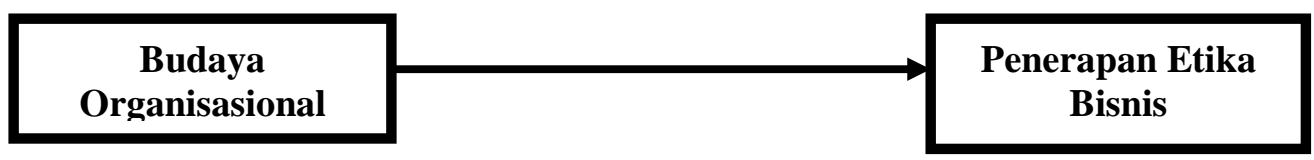

Gambar 3. Model penelitian

Data yang dibutuhkan peneliti adalah data primer dan data sekunder. Untuk memperoleh data primer yang diperlukan peneliti menggunakan instrumen penelitian berupa kuesioner. Kuesioner yang digunakan berbentuk close-ended questionnaire, dimana responden memilih alternatif yang telah ditetapkan oleh peneliti (Sekaran, 2003). Kuesioner dibagi menjadi dua bagian. Bagian pertama 
berisi pertanyaan-pertanyaan mengenai data demografi responden berupa usia, jenis kelamin, pendidikan terakhir, status, divisi/jabatan dan masa kerja. Bagian kedua berisi item-item pertanyaan dari setiap variabel dalam penelitian. Keseluruhan item dalam kuesioner akan diukur menggunakan skala pengukuran Likert 6 point. Data primer juga diperoleh dari hasil wawancara dengan manajer unit di perusahaan. Data sekunder diperoleh dari dokumen-dokumen perusahaan. Data sekunder ini digunakan untuk mendukung penelitian yang sedang dilakukan. Populasi dalam penelitian ini adalah karyawan perusahaan pada industri penerbangan di Indonesia. Teknik pengambilan sampel yang digunakan adalah judgment sampling, dimana responden dipilih karena dianggap dapat memberikan informasi yang dibutuhkan (Sekaran, 2003). Ukuran sampel dalam penelitian ini adalah 79 responden. Dalam penelitian ini, responden adalah karyawan perusahaan pada industri penerbangan Indonesia yang masa kerjanya lebih dari 2 tahun. Dengan masa kerja yang lebih dari 2 tahun dianggap telah memahami budaya organisasional yang terdapat di perusahaan.

Untuk menguji keabsahan data yang telah dikumpulkan, maka peneliti melakukan uji validitas dan uji reliabilitas. Perhitungan validitas instrumen dilakukan dengan memakai rumus teknik korelasi produk moment dan triangulation. Reliabilitas dalam penelitian ini diukur melalui konsistensi internal antar item dengan melihat koefisien Cronbach's Alpha. Pembahasan hasil penelitian dilakukan dengan cara meninjau hasil penelitian secara kritis dengan teori yang relevan dan informasi masyarakat yang diperoleh dari penelitian (Moleong, 2004). Pada penelitian ini, untuk data primer yang berasal dari pengisian kuesioner peneliti menggunakan uji F, regresi sederhana dan koefisien determinasi. Sementara, untuk menganalisis hasil wawancara dengan Manajer Unit perusahaan menggunakan content analysis (Yin, 2011).

\section{HASIL DAN PEMBAHASAN}

Responden pada penelitian ini adalah karyawan-karyawan pada empat perusahaan industri penerbangan di Indonesia sejumlah 79 responden. Seluruh karyawan mengisi kuesioner dan hasilnya dapat digunakan dalam analisis data. Sementara wawancara dilakukan kepada General Manager Perusahaan. Wawancara dilakukan dengan mengajukan pertanyaan semi-struktur yang berkaitan dengan budaya perusahaan dan kode etik serta penerapan etika di perusahaan.

\section{Karakteristik Responden}

Sebelum menjawab pertanyaan inti mengenai budaya perusahaan dan penerapan etika bisnis, responden diminta memberikan profilnya meliputi jenis kelamin, usia, pendidikan, dan masa kerja. Berdasarkan hasil isian kuesioner dari 79 responden diantaranya $73,42 \%$ berjenis kelamin pria, $48,10 \%$ berusia antara $21-25$ tahun, 50,53\% berpendidikan SLTA/Sederajat, dan 65,82\% telah memiliki masa kerja 1-5 tahun. Data lengkap mengenai karakteristik responden tersaji pada Tabel 1.

Tabel 1 Karakteristik Responden

\begin{tabular}{llrr}
\hline \multicolumn{1}{c}{ Profil } & \multicolumn{1}{c}{ Desckripsi } & Frekuensi & Persentase (\%) \\
\hline \multirow{2}{*}{ Jenis Kelamin } & Laki-laki & 58 & 73,42 \\
& Perempuan & 21 & 26,58 \\
& Total & 79 & 100,00 \\
\hline Usia & $21-25$ & 38 & 48,10 \\
& $26-30$ & 23 & 29,11 \\
& $31-35$ & 15 & 18,99 \\
& $36-40$ & 2 & 2,53
\end{tabular}




\begin{tabular}{llrr} 
& $41-45$ & 1 & 1,27 \\
& $45-50$ & 0 & 0,00 \\
& $>50$ & 0 & 0,00 \\
& Total & 79 & 100,00 \\
\hline Pendidikan & SLTA/Sederajat & 40 & 50,53 \\
& Diploma & 12 & 15,19 \\
& Strata 1 & 27 & 34,18 \\
& Strata 2 & 0 & 0,00 \\
& Strata 3 & 0 & 0,00 \\
& Total & 79 & 100,00 \\
\hline Masa Kerja & 1 s.d 5 tahun & 52 & 65,82 \\
& 6 s.d 10 tahun & 15 & 18,99 \\
& 11 s.d 15 tahun & 10 & 12,66 \\
& 16 s.d 20 tahun & 2 & 2,53 \\
& $>21$ tahun & 0 & 0 \\
& Total & 79 & 100,00 \\
\hline
\end{tabular}

Sumber: Data primer yang diolah (2018)

\section{Pengaruh Budaya Organisasional Terhadap Penerapan Etika Bisnis}

Untuk mengetahui pengaruh budaya organisasi terhadap penerapan etika bisnis maka dilakukan melalui uji F, regresi linier sederhana dan koefisien determinasi dengan bantuan program komputer IBM SPSS Statistics 15 Version 15.0.1 Multilingual dengan sistem operasi Windows XP. Hasil analisis Uji F tersaji pada Tabel 2.

Tabel 2

\begin{tabular}{llrrrrr}
\hline Model & & $\begin{array}{c}\text { Sum of } \\
\text { Squares }\end{array}$ & Df & $\begin{array}{c}\text { Mean } \\
\text { Square }\end{array}$ & F & Sig. \\
\hline 1 & Regression & 79,494 & 1 & 79,494 & 17,922 &, $000(\mathrm{a})$ \\
& Residual & 341,544 & 77 & 4,436 & & \\
& Total & 421,038 & 78 & & & \\
\hline
\end{tabular}

Tabel 2 menunjukkan apakah ada pengaruh nyata (signifikan) variabel Budaya Organisasional (X) terhadap variabel Etika Bisnis (Y). Dari uji Annova atau uji F hitung sebesar 17,922 dengan nilai signifikan 0,000. Berdasarkan hasil tersebut ini dapat disimpulkan bahwa $\mathrm{H}_{0}$ ditolak $\mathrm{H}_{1}$ diterima, yaitu terdapat pengaruh budaya organisasional terhadap penerapan etika bisnis di perusahaan penerbangan.

Analisis regresi linier sederhana digunakan untuk mengukur besarnya pengaruh variabel bebas terhadap variabel tergantung dan memprediksi variabel tergantung dengan menggunakan variabel bebas. Dalam hal ini untuk mengetahui pengaruh Budaya Organisasional terhadap Etika Bisnis pada perusahaan industri penerbangan. Output dari program IBM SPSS Statistic 15 diperoleh nilai regresi seperti yang tertera pada tabel 3 .

Tabel 3

\begin{tabular}{llccccc}
\hline Model & \multicolumn{2}{c}{$\begin{array}{c}\text { Unstandardized } \\
\text { Coefficients }\end{array}$} & $\begin{array}{c}\text { Standardized } \\
\text { Coefficients }\end{array}$ & t & Sig. \\
\hline & B & Std. Error & Beta & B & $\begin{array}{c}\text { Std. } \\
\text { Error }\end{array}$ \\
\hline 1 & $\begin{array}{l}\text { (Constant) } \\
\text { Budaya }\end{array}$ & 12,099 & 1,554 & & 7,783 &, 000 \\
& &,- 283 &, 067 &,- 435 & $-4,233$ &, 000 \\
& & & & & & \\
\hline
\end{tabular}




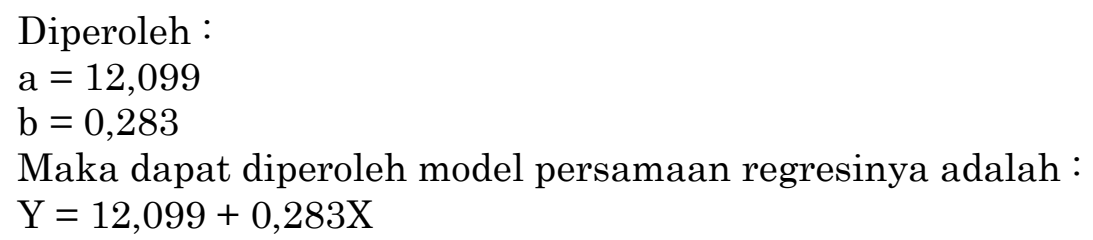

Dari analisis regresi diatas dapat diketahui bahwa nilai dari a adalah 12,099. Nilai ini menunjukkan bahwa pada saat Budaya Organisasi (X) bernilai nol, maka Etika Bisnis (Y) akan bernilai 12,099. Sedangkan nilai dari b yaitu sebesar 0,283 menunjukkan bahwa ketika terjadi kenaikan Budaya Organisasi sebesar satu satuan, maka Etika Bisnis akan meningkat sebesar 0,283 satuan. Selain itu terlihat tanda positif (+) yang berarti adanya pengaruh yang positif antara Budaya Organisasi dan Etika Bisnis.

Analisis Koefisien Korelasi Person adalah untuk mengetahui adanya derajat/kekuatan hubungan Budaya Organisasi terhadap Etika Bisnis pada perusahaan industri penerbangan. Output dari program IBM SPSS Statistics 15 diperoleh nilai koefisien korelasi seperti yang tertera pada tabel 4 .

Table 4

\begin{tabular}{llrrr}
\hline Model & R & R Square & $\begin{array}{c}\text { Adjusted R } \\
\text { Square }\end{array}$ & $\begin{array}{c}\text { Std. Error of the } \\
\text { Estimate }\end{array}$ \\
\hline 1 &, $435(\mathrm{a})$ &, 189 &, 178 & 2,10609 \\
\hline
\end{tabular}

Berdasarkan analisis diatas, maka didapatkan nilai koefisien korelasi sebesar 0,435. Hal ini menunjukkan bahwa ada hubungan antara Budaya Organisasional terhadap Etika Bisnis pada di perusahaan industri penerbangan. Sementara untuk menghitung besarnya pengaruh Budaya organisasional tehadap Etika Bisnis, berdasarkan koefisien korelasi person dengan mempergunakan rumus koefisien determinasi sebagai berikut:

$$
\begin{aligned}
\mathrm{KD} & =(\mathrm{r})^{2} \times 100 \% \\
& =(0,435)^{2} \times 100 \% \\
& =18,92 \%
\end{aligned}
$$

Dari hasil diatas maka Budaya Organisasi memberikan pengaruh sebesar 18,92\% terhadap Etika Bisnis pada perusahaan industri penerbangan. Sementara sisanya sebesar $81,08 \%$, disebabkan oleh variabel lainnya.

\section{Penerapan Standar Etika di Perusahaan Penerbangan Indonesia (Studi Perusahaan Ground Handling)}

Perusahaan ground handling yang menjadi studi kasus pada penelitian ini telah memiliki kode etik yang merupakan dokumen tertulis berupa prinsip filosofis dan mengartikulasikan nilai-nilai yang dipeluk oleh organisasi. Perusahaan selalu menerapkan kode etik yang berisi standar etika yang berlaku di perusahaan. Kemudian, perusahaan juga telah memiliki nilai budaya yang menjadi kerangka acuan untuk menyamakan gerak dan langkah seluruh jajaran organisasi secara konsisten untuk mencapai tujuan yang telah ditetapkan. Perusahaan merumuskan 3 (tiga) nilai budaya yang akan menjadi pedoman perilaku setiap insan perusahaan, yaitu Delight, yang terdiri:

1. Decisive and Compliance, yang artinya agresif dan cekatan dalam menangkap peluang serta cepat mengambil keputusan dengan tepat dan akurat sehingga mampu menghadapi tantangan dan perubahan yang akan datang dengan tetap memastikan kepatuhan terhadap aturan, kebijakan dan hukum yang berlaku. 
2. Integrity, yang artinya jujur terhadap diri sendiri dan orang lain serta disiplin dalam menyelaraskan pikiran, perkataan dan perbuatan.

3. Customer Delight, yang artinya memberikan pelayanan dengan tulus dan bergairah melebihi harapan pelanggan.

Budaya Organisasional pada perusahaan ground handling di Indonesia mendukung penerapan etika bisnis perusahaan. Hal ini terlihat berdasarkan hasil jawaban yang menunjukkan dari uji Annova atau uji $\mathrm{F}$ hitung sebesar 17,922 dengan nilai signifikansi 0,000. Dan berdasarkan penelitian ini dapat disimpulkan bahwa $\mathrm{H}_{0}$ ditolak dan $\mathrm{H}_{1}$ diterima, sehingga hipotesis yang menyatakan bahwa variabel Budaya Organisasional berpengaruh terhadap Etika Bisnis di perusahaan penerbangan. Penerapan etika bisnis sangat diperlukan agar perusahaan dapat bertahan dan tangguh dalam menghadapi persaingan yang semakin ketat dan diharapkan dapat menjadi sarana untuk mencapai visi, misi dan tujuan perusahaan secara lebih baik. Oleh karena itu, seluruh stakeholder perusahaan harus mempunyai budaya organisasional dan menerapkannya agar etika bisnis pun dapat diterapkan sehingga citra perusahaan tetap terjaga.

\section{PENUTUP}

Hasil penelitian menunjukkan bahwa perusahaan telah memiliki kode etik (code of conduct) dan nilai-nilai budaya yang menjadi panduan bagi karyawan dan stakeholder yang selalu disosialisasikan oleh perusahaan. Nilai budaya tersebut menjadi kerangka acuan untuk menyamakan gerak dan langkah seluruh jajaran organisasi secara konsisten untuk mencapai tujuan yang telah ditetapkan. Budaya Organisasional pada perusahaan di industri penerbangan Indonesia mendukung penerapan etika bisnis perusahaan. Berdasarkan hasil uji $\mathrm{F}$ hitung sebesar 17,922 dengan nilai signifikan 0,000 , menunjukkan bahwa terdapat pengaruh budaya organisasional terhadap penerapan etika bisnis perusahaan. Berdasarkan hasil regresi linear sederhana menunjukkan adanya pengaruh positif antara budaya organisasional dan etika bisnis. Berdasarkan hasil koefisien determinasi menunjukkan bahwa budaya organisasional memberikan pengaruh sebesar $18,92 \%$ terhadap penerapan etika bisnis, sedangkan sisanya $81,08 \%$ disebabkan oleh variabel lainnya.

\section{REFERENSI}

Griffin, R. W \& Ebert, R. (2010). Bisnis. Edisi Kedelapan. Jakarta: Penerbit Erlangga. Keraf, S, \& Imam, R.H. (1998). Etika Bisnis. Yogyakarta: Penerbit Kanisius

Kreitner, R., \& Kinicki, A. (2010). Organizational Behavior Ninth Edition. New York: McGraw-Hill Companies Inc.

Militaru, C \& Zanfir, A. (2012). The influence of organizational culture over the ethical principles in international business. International Journal of Academic Research in Accounting, Finance and Management Science, Vol 2, Special Issues 1, pp 26-33.

Moleong, L.J. (2004). Metodologi Penelitian Kualitatif. Bandung: PT Remaja Rosdakarya.

Schein, E.H. (Juni ,1996). Culture: The missing concept in organization studies. Administrative Science Quarterly, hal 236.

Schein, E.H. (1992). Organizational Culture and Leadership. San Fransisco: JousseyBass.

Sekaran, U. (2003). Research Method for Business. New York: John Wiley and Sons, Inc.

Stevens, Betsy. (2008). Corporate ethical codes: Effective instruments for influencing 
behavior. Journal of Business Ethics, 78: 601-609.

Stevens, B. (1996). Using the competing values framework to assess corporate ethical codes. Journal of Business Communication 33 (1), 71-83.

$\mathrm{Su}, \mathrm{Hwann}-Y a n n$. (2014). Business ethics and the development of intellectual capital. Journal of Business Ethics,119: 87-98.

Sutoyo, Anwar. (2009). Pemahaman Individu, Observasi, Checklist, Interview, Kuesioner dan Sosiometri. Yogyakarta: Pustaka Pelajar.

Thompson, J. W. (1995). The renaissance of learning in business. Dalam F. Kofman, \& P. Senge, Learning organizations developing cultures or tomorrow's workplace. Portland, Oregon: Productivity Press.

Wah, I. (Juni 1999). Lip-srvice ethics program prove ineffective. Management Review, hal 9.

Wah, I. (Mei 1999). Lies in the executive wing. Management Review, hal 9.

Velasquez, Manuel G. (2006). Business Ethics : Concepts and Cases $6^{e d}$. New Jersey: Pearson Education International.

Yin, R.K. (2011). Qualitative research from start to finish. London: The Guilford Press. 